\title{
PROSPECTIVE EVALUATION OF BLUNT ABDOMINAL TRAUMA BY MULTIDETECTOR COMPUTED TOMOGRAPHY
}

\author{
Murali Belman', Mandapal Toka²
}

${ }_{1}^{1}$ Associate Professor, Department of Radiology and Imaging Sciences, Bhaskar Medical College and General Hospital, Yenkapally, Telangana, India.

2Professor, Department of Radiology and Imaging Sciences, Bhaskar Medical College and General Hospital, Yenkapally, Telangana, India.

ABSTRACT
BACKGROUND
One of the most important aspects of blunt abdominal trauma is the need for a speedy evaluation and the resource intensive
management that is required. It may be noted that the mortality, morbidity and the associated costs are substantially high. CT is
the technique of choice for initial examination of hemodynamically stable patients after blunt abdominal trauma. We wanted to
study different traumatic pathologies of the abdomen in blunt trauma with the aid of multidetector CT and to grade the organ
injuries as per the "Organ Injury Scale (OIS)".

\section{METHODS}

A prospective observational study was done on patients with abdominal trauma between May 2015 and May 2017. A total of 70 patients were included in the study on whom CT was performed.

\section{RESULTS}

70 patients with history of blunt abdominal injury were evaluated. The average age of the group was 30.5 \pm 29.4 (range from 5-70) with the sex distribution in the group being 54:16 (M: F). 46 (66\%) of the 70 patients were admitted due to road traffic accidents (RTA), making it the most common form of blunt abdominal injury in this study; followed by 7 (10\%) due to fall from heights. Spleen was the organ that was injured the most which amounted to $19(41 \%)$ followed by the liver which accounted for 11 (23\%) and kidney which accounted for 6 (13\%).

\section{CONCLUSIONS}

Intravenous Contrast Enhanced MDCT is the imaging modality of choice in effectively evaluating blunt trauma abdomen in haemodynamically stable patients. MDCT abdomen not only detects intra-abdominal injury but it also detects other associated important injuries such as haemothorax, lung injuries, fractures of lower ribs, fractures of spine and pelvis.

HOW TO CITE THIS ARTICLE: Belman M, Toka M. Prospective evaluation of blunt abdominal trauma by multidetector computed tomography. J. Evolution Med. Dent. Sci. 2019;8(14):1156-1162, DOI: 10.14260/jemds/2019/257

\section{BACKGROUND}

Blunt abdominal trauma is one of the commonest injuries. Blunt abdominal trauma usually occurs due to road traffic accidents; fall from height, assaults or during sports. Prevalence of intra-abdominal injuries varies widely and rapid diagnosis is essential. Appropriate diagnostic work up and treatment is critical to ensure patient survival to decrease mortality and morbidity. ${ }^{1}$ Patients with abdominal trauma present a frequent diagnostic dilemma because of low accuracy of physical examination and clinical diagnosis. ${ }^{2}$

Formerly, diagnostic peritoneal lavage (DPL) was the procedure of choice for the quick diagnosis of a hemoperitoneum in patients with blunt abdominal trauma. DPL, first described in 1965, resulted in a decrease in mortality and morbidity following abdominal trauma. ${ }^{3}$ In general, FAST examination has replaced the use of DPL, because DPL is an invasive procedure and provides no information about which organ is injured, resulting in a high rate of negative or non-therapeutic laparotomies. 4

'Financial or Other Competing Interest': None.

Submission 07-03-2018, Peer Review 27-04-2018,

Acceptance 02-05-2018, Published 08-04-2019.

Corresponding Author:

Dr. Murali Belman,

Plot No. 702 A, Road No. 36,

Jubilee Hills, Hyderabad-500033, Telangana, India.

E-mail:drbelmanmurali@gmail.com

DOI: $10.14260 /$ jemds $/ 2019 / 257$
FAST is useful in trauma evaluation to identify intraabdominal fluid, a herald of significant organ injury, with a sensitivity of $90-93 \%$. FAST can be performed simultaneously with resuscitation efforts during the initial trauma management and can be completed rapidly. FAST is, therefore, also useful in hemodynamically unstable patients. ${ }^{5}$ Continued intraabdominal haemorrhage in the setting of a compromised hemodynamic status, despite aggressive resuscitation efforts, is usually an indication for emergent surgery. A FAST (Focused assessment with sonography for trauma) study that shows abundant free fluid (Blood) in the abdomen often precedes the decision to perform emergency laparotomy. Despite its high specificity, ultrasonography has an unexpectedly low sensitivity for the detection of both free fluid and organ lesions. In haemodynamically stable patient with clinically suspected abdominal trauma, another assessment (e.g. helical computed tomography) must be performed regardless of the initial ultrasonographic findings. ${ }^{6}$

CECT imaging is the diagnostic tool of choice for the evaluation of abdominal injury due to blunt trauma in haemodynamically-stable patients. ${ }^{7}$ CT is superior to clinical evaluation and diagnostic peritoneal lavage for diagnosing important abdominal injuries. ${ }^{8-9}$ In addition, an abdominal CT scan can assist in the evaluation of coexisting abdominal injuries such as thoracic injuries. ${ }^{10}$ MDCT scanning with intravenous contrast has numerous advantages- 
1. First, the detection of injuries related to the liver, spleen and kidney can be reliably determined, with a sensitivity of $90-100 \%$.

2. Second, active bleeding (A contrast blush), pseudoaneurysms and post-traumatic arteriovenous fistulas can be diagnosed, and the localization of these vascular injuries can also be established.

3. Third, the MDCT scan plays a decisive part in the order of treatment if more than one injury is present. ${ }^{11}$

In approximate order of frequency, the most commonly injured abdominal organs and structures are the spleen, liver, kidneys, small bowel and/or mesentery, bladder, colon and/or rectum, diaphragm, pancreas, and major vessels, ${ }^{12}$ and multiple organs are often affected simultaneously. Conservative nonsurgical therapy is preferred for all except for the most severe injuries affecting the solid viscera. ${ }^{13-16} \mathrm{CT}$ is also used for grading the solid organ injuries. In haemodynamically stable patients with suspected injury to abdomen MDCT with intravenous contrast is the investigation of choice.

\section{Objective of The Study}

The primary objective of this paper is to study different traumatic pathologies of the abdomen in blunt trauma with the aid of multidetector CT and to grade the organ injuries as per the "Organ Injury Scale". This paper also correlates the image findings with both surgical and clinical findings and establish the accuracy of CT in detecting various lesions.

\section{METHODS}

The study was conducted as a prospective observational study between May 2015 and May 2017. Imaging was performed on the Toshiba Alexion CT scan machine and sections from above the level of Diaphragm to Pubic symphysis. Plain study was first performed, and contrast was injected to get the arterial, venous and delayed phases as needed. Non-Ionic Contrast media (OMNIPAQUE 350) was used and the flow rate was adjusted to $4 \mathrm{ml} / \mathrm{s}$ by an injection pump for every $1.5 \mathrm{ml} / \mathrm{Kg}$ of body weight.

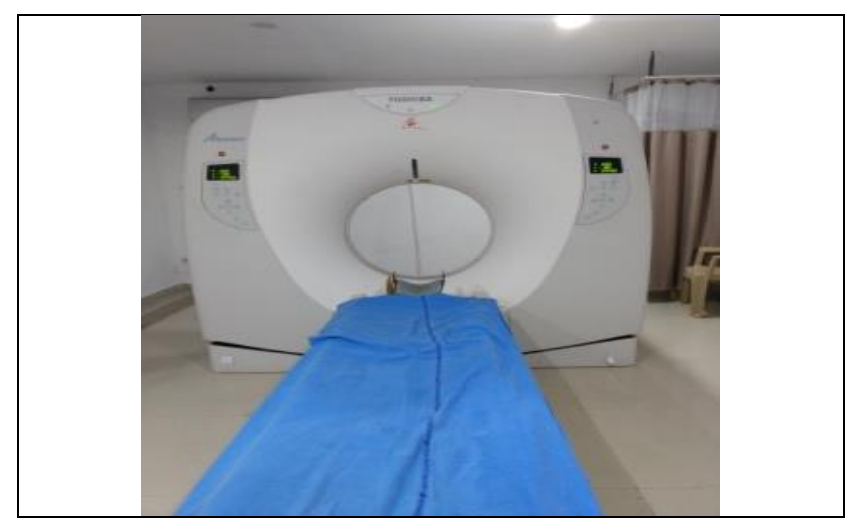

\section{Inclusion Criteria}

1. Clinical suspicion of abdominal trauma.

2. All poly- trauma cases.

3. Hemodynamically stable patients.

4. Cases with positive ultrasound findings.

\section{RESULTS}

The study included 70 patients with history of blunt abdominal injury. The average age of the group was $30.5 \pm$ 29.4 (range from 5-70) with a sex distribution in the group being 54:16 (M: F). The most commonly affected age group was 21-30 years followed by 31-40 years (Table 1) and this study highlighted that the majority of the cases were of 2140-year age group.

\begin{tabular}{|c|c|c|}
\hline Sl. No. & Age Group & Number (\%) \\
\hline 1 & $01-10$ & $03(04 \%)$ \\
\hline 2 & $11-20$ & $9(13 \%)$ \\
\hline 3 & $21-30$ & $26(37 \%)$ \\
\hline 4 & $31-40$ & $20(28 \%)$ \\
\hline 5 & $41-50$ & $08(11 \%)$ \\
\hline 6 & $51-60$ & $02(3 \%)$ \\
\hline 7 & $61-70$ & $02(3 \%)$ \\
\hline \multicolumn{2}{|c|}{ Table 1. Age Distribution (N=70) } \\
\hline
\end{tabular}

Most of the patients admitted were victims of vehicular accidents. Table 2 blow indicates the mode of injury that were encountered in our study.

\begin{tabular}{|c|c|c|}
\hline Sl. No. & Type of Injury & No. of Patients (\%) \\
\hline 1 & RTA & $46(66 \%)$ \\
\hline 2 & Fall from Heights & $07(10 \%)$ \\
\hline 3 & Automobile vs Pedestrian & $07(10 \%)$ \\
\hline 4 & Assault & $04(6 \%)$ \\
\hline 5 & $\begin{array}{c}\text { Others (Bull Horn Injury, Hit by } \\
\text { Projectile Object) }\end{array}$ & $06(8 \%)$ \\
\hline \multicolumn{2}{|c|}{ Total } & $\mathbf{7 0 ~ ( 1 0 0 \% )}$ \\
\hline \multicolumn{2}{|c|}{ Table 2. Mode of Injury } \\
\hline
\end{tabular}

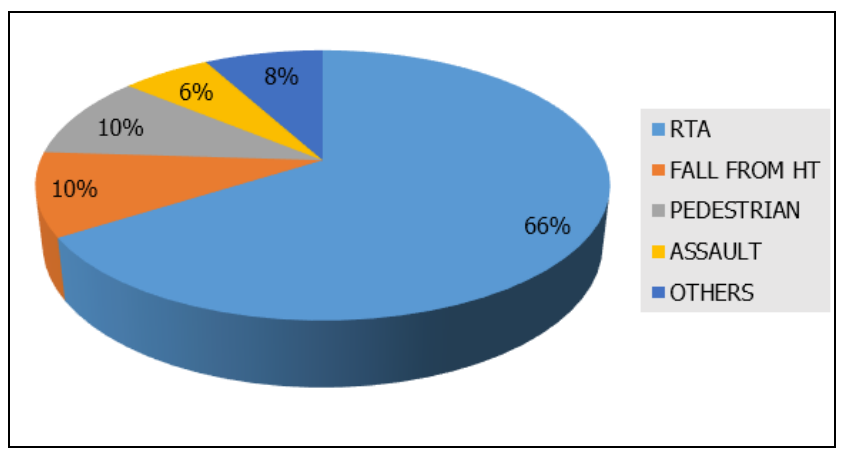

$46(66 \%)$ of the 70 patients were admitted due to road traffic accidents (RTA) making it the most common form of blunt abdominal injury in this study followed by 7 (10\%) due to fall from heights.

\begin{tabular}{|c|c|c|}
\hline Sl. No. & Organ Injured & No. of Organs (\%) \\
\hline 1 & Spleen & $19(41 \%)$ \\
\hline 2 & Liver & $11(23 \%)$ \\
\hline 3 & Kidneys & $06(13 \%)$ \\
\hline 4 & Hollow Viscus & $04(9 \%)$ \\
\hline 5 & Mesentery & $03(8 \%)$ \\
\hline 6 & Pancreas & $01(2 \%)$ \\
\hline 7 & Urinary Bladder & $01(2 \%)$ \\
\hline \multirow[t]{2}{*}{8} & Vascular Injury & $01(2 \%)$ \\
\hline & Total & $46(100 \%)$ \\
\hline \multicolumn{3}{|c|}{$\begin{array}{l}\text { Table 3. Distribution of Organ Injuries Sustained Due to } \\
\qquad \text { RTA's }(N=46)\end{array}$} \\
\hline
\end{tabular}




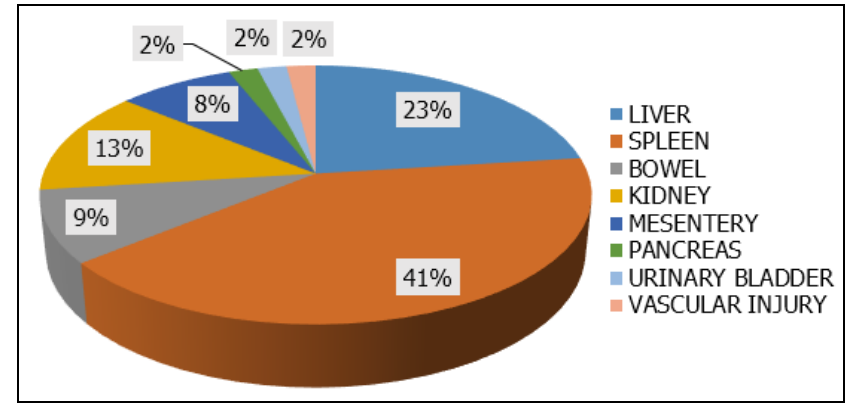

Of the 46 injuries sustained due to RTA's the most common organ that was affected was the spleen which amounted to 19 (41\%) followed by the liver which accounted for $11(23 \%)$ and kidney which accounted for $6(13 \%)$. There were 3 cases of mesenteric tear, 4 cases of bowel injury, 6 cases of renal trauma, 1 case of pancreatic trauma, 1 case of urinary bladder trauma and 1 case of vascular injury as shown in Table 3.

Case Examples

Splenic Injury
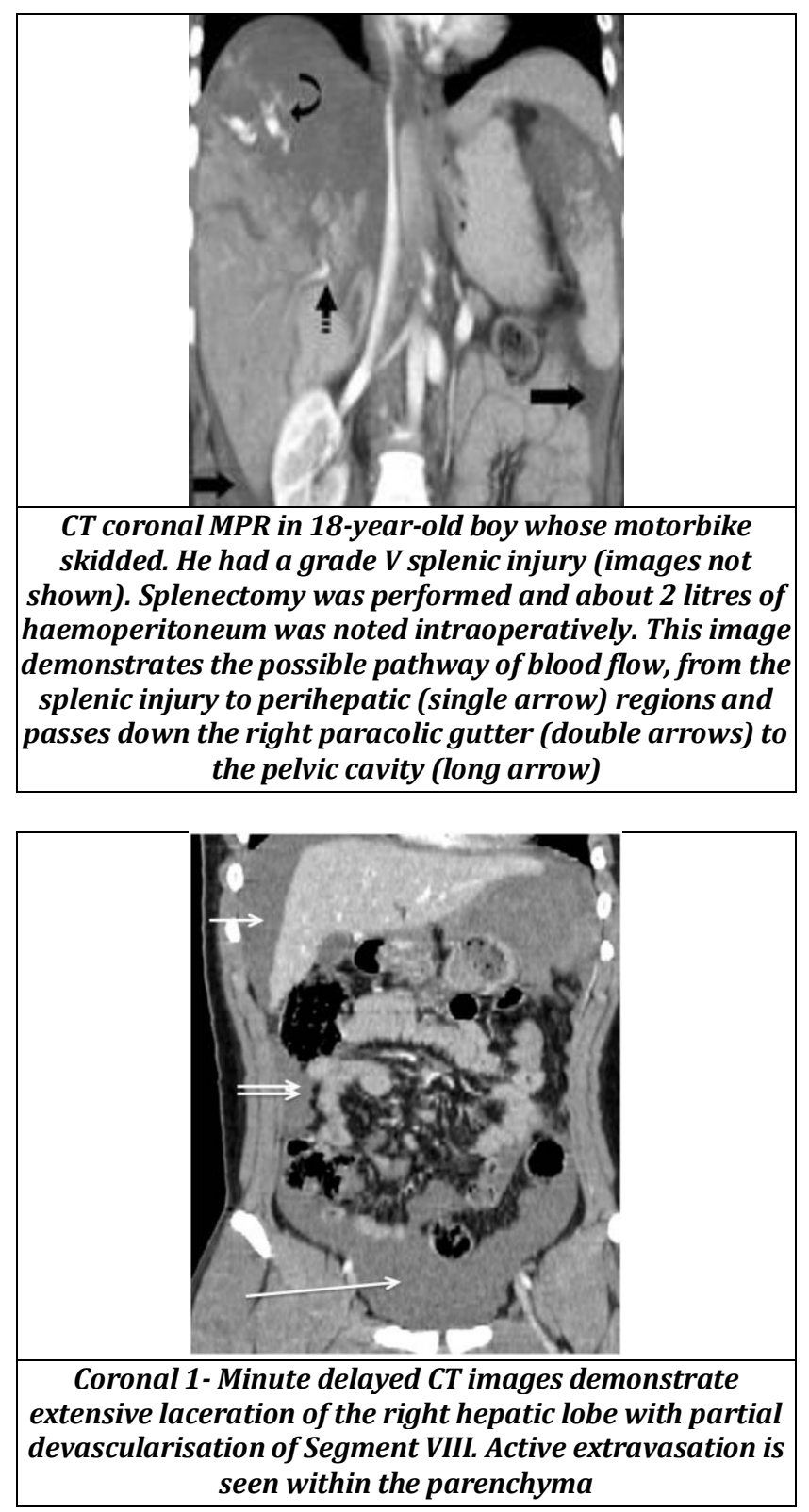

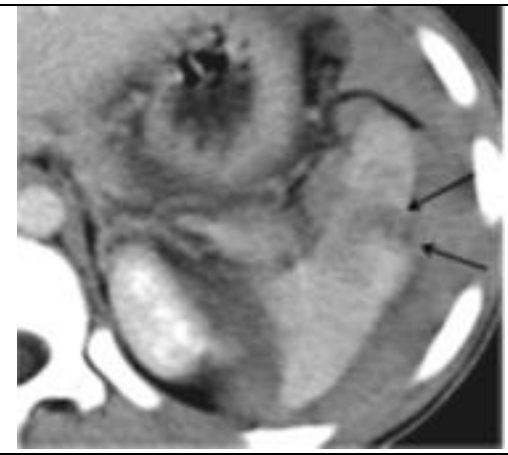

CT scan showing splenic laceration in a 13-year-old boy, a pillion rider of a skidded motorbike. Splenic laceration is

seen as irregular, linear region of low attenuation (arrows). A 4-cm laceration was identified at the tip of the spleen during surgery and splenectomy was performed.

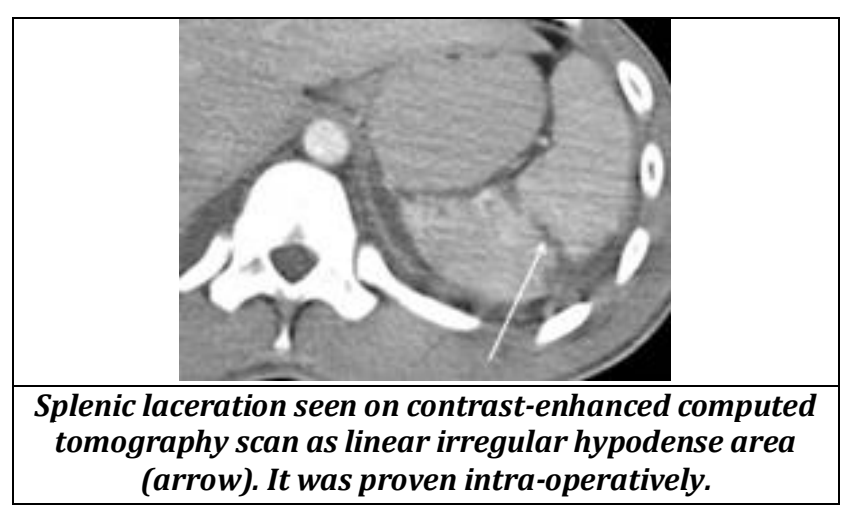

Liver Injury

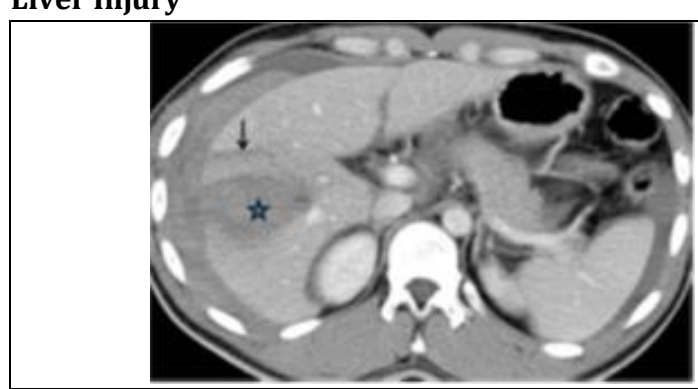

CT scan of liver injury in a 23-year-old man with MVA. Liver laceration is shown on CT as a non-enhancing irregular, linear low attenuation area (arrow) with associated intraparenchymal haematoma (star), which appears as a region of decrease attenuation compared to the rest of the enhanced liver parenchyma. He was managed surgically.

\begin{tabular}{|c|} 
Grade IV Hepatic Injury. Contrast-enhanced CT scan shows \\
multiple hepatic lacerations in the right hepatic lobe, \\
resulting in parenchymal disruption of about $50 \%$ of the \\
lobe.
\end{tabular}


Pancreatic Injury

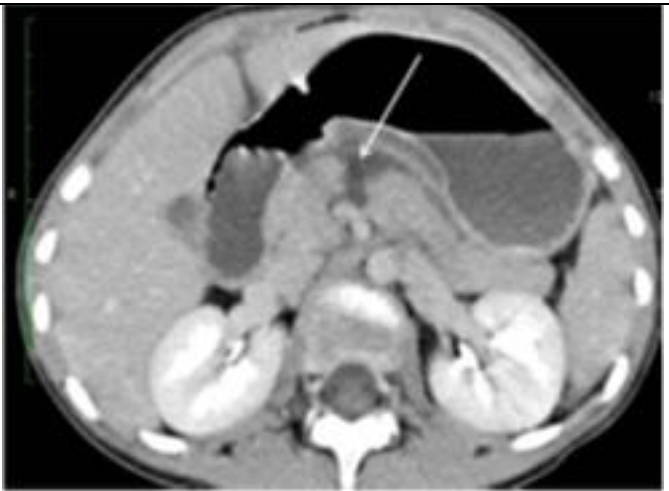

CT scan of pancreatic transection in a 9-year-old girl with 'bicycle-handle' injury. Diagnosis was delayed and CT scan performed 2 days after the incident showed a total transection of the body of pancreas (arrow). This was later complicated by a pseudocyst formation that required a percutaneous drainage.

Renal Injury

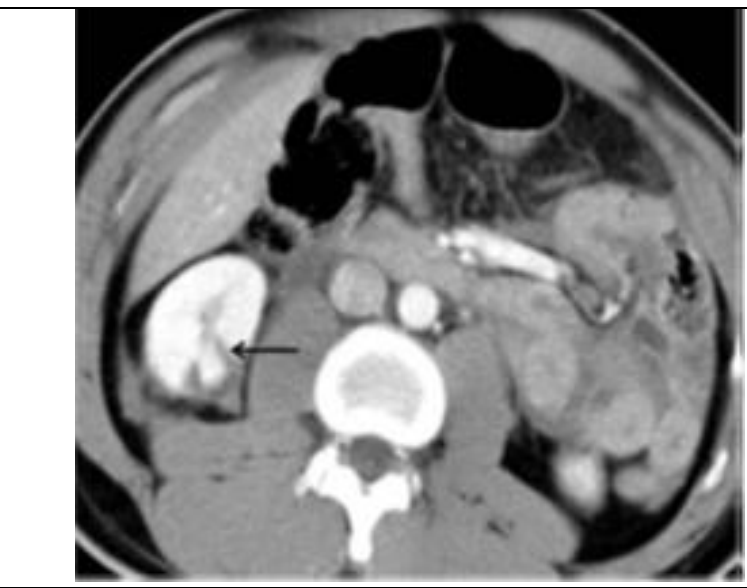

CT of renal laceration in a 32-year-old man with MVA. The right renal lacerations are shown as irregular, linear low attenuation areas within the parenchyma (arrow), which does not involve the collecting systems. He was managed conservatively with an uneventful recovery.

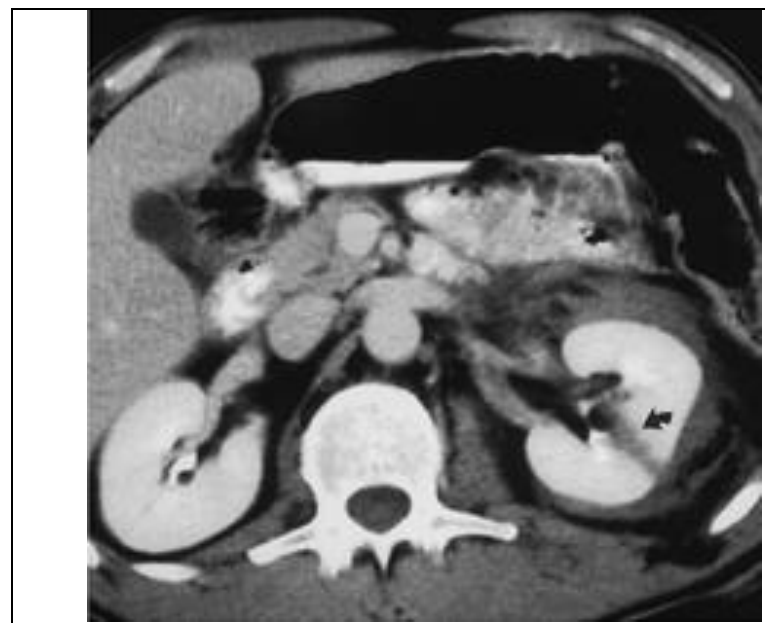

CT scan of another patient shows a deep, full-thickness parenchymal fracture (arrow) with only minimal perirenal bleeding.
Bladder Injury

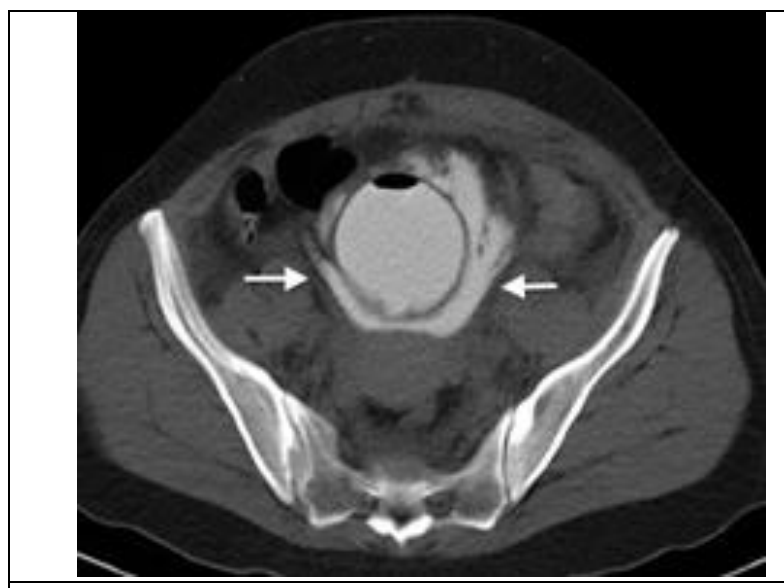

CT of pelvis after retrograde instillation of water soluble contrast material through a foleys catheter demonstrating extravasation of contrast into the perivasicular space. The leak is extra peritoneal since extravasated contrast is limited to the perivesiclar fasial planes of the pelvis.

Bowel and Mesenteric Injury

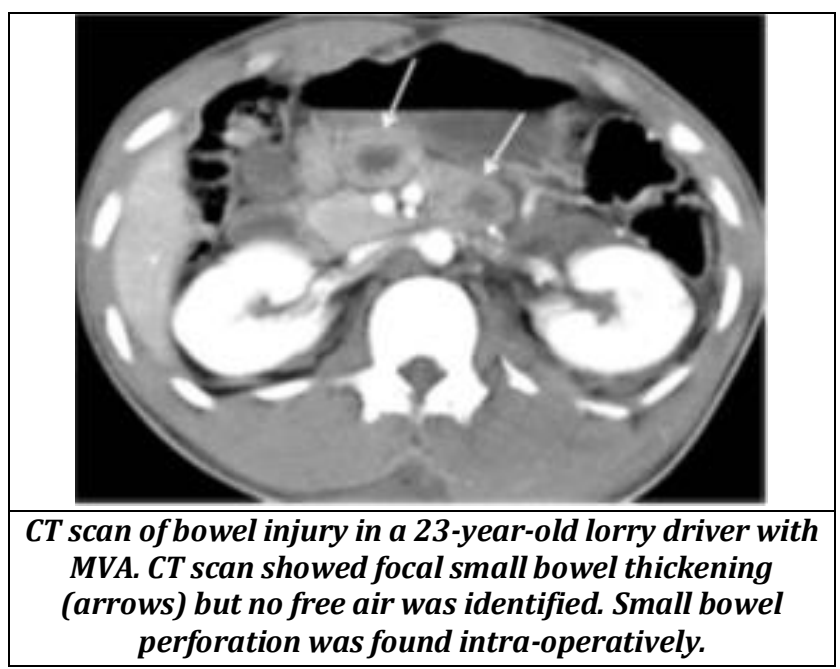

\begin{tabular}{|c|c|c|}
\hline $\begin{array}{c}\text { Sl. } \\
\text { No. }\end{array}$ & Organ Injured & $\begin{array}{c}\text { No. of Organs } \\
\text { (\%) }\end{array}$ \\
\hline 1 & Rib Fracture & $12(31 \%)$ \\
\hline 2 & Haemothorax & $10(26 \%)$ \\
\hline 3 & Lung Injury & $06(15 \%)$ \\
\hline 4 & Spine Fracture & $02(6 \%)$ \\
\hline 5 & Pelvis Fracture & $03(8 \%)$ \\
\hline \multicolumn{2}{|c|}{ Total } & $\mathbf{3 3 ( 1 0 0 \% )}$ \\
\hline \multicolumn{2}{|c|}{ Table 4. Associated Injuries $\mathbf{N = 3 8 )}$} \\
\hline
\end{tabular}

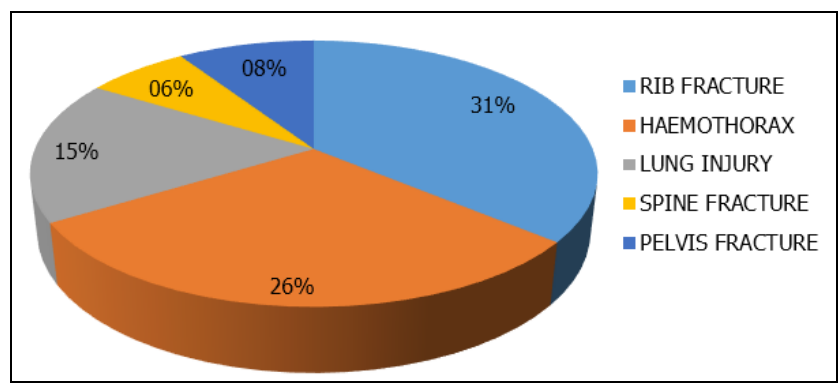




\section{DISCUSSION}

CT was found to be suitable and reliable method for the diagnosis of abdominal trauma and in providing the accuracy for identifying injuries and grading them thereby suggesting possible methods of management. The following section discusses these details.

\section{CT Findings of Abdominal Trauma and Grading of} Injuries/Haemoperitoneum

Haemoperitoneum was seen in 29 cases (76\%). The CT quantification of hemoperitoneum as described by Federle et al is classified into three categories as-

1. Small (Fluid in only one space; $100-200 \mathrm{ml}$ )

2. Moderate (fluid in two or more spaces; $200-500 \mathrm{ml}$ ) and

3. Large (fluid in all spaces or pelvic anterior/superior to urinary bladder; $>500 \mathrm{ml}$ ).

\begin{tabular}{|c|c|}
\hline Description & No. of Cases \\
\hline Small & 11 \\
\hline Moderate & 8 \\
\hline Large & 10 \\
\hline
\end{tabular}

Of these 29 cases, 20 cases were operated, and it was observed that 11 cases were positive for solid organ injury. In 4 cases there was associated pneumoperitoneum, increasing the suspicion to bowel injury. In 3 cases mesentery was injured which was not detected by CECT. In one case GR-II splenic injury was missed on CECT and was reported as Haemoperitoneum with no obvious solid organ injury which was later detected on surgery. The remaining 9 cases were positive for Haemoperitoneum associated with solid organ injury on MDCT and managed conservatively.

\section{Splenic Injury}

Spleen was the most commonly injured solid organ in our study. Splenic injuries were graded according to the table given below-

\begin{tabular}{|c|c|c|}
\hline Grade & & Injury Description \\
\hline \multirow[t]{2}{*}{ I } & Haematoma & Subcapsular, $<10 \%$ Surface Area \\
\hline & Laceration & $\begin{array}{l}\text { Capsular Tear, } \\
<1 \mathrm{~cm} \text { Parenchymal Depth }\end{array}$ \\
\hline \multirow[t]{2}{*}{ II } & Haematoma & $\begin{array}{l}\text { Subcapsular, } 10-50 \% \text { Surface Area } \\
\text { Intraparenchymal, }<5 \mathrm{~cm} \text { Diameter }\end{array}$ \\
\hline & Laceration & $\begin{array}{l}\text { 1-3 cm Parenchymal Depth Not } \\
\text { Involving A Parenchymal Vessel }\end{array}$ \\
\hline \multirow[t]{2}{*}{ III } & Haematoma & $\begin{array}{l}\text { Subcapsular, } \\
>50 \% \text { Surface Area or Expanding. } \\
\text { Ruptured Subcapsular or Parenchymal } \\
\text { Haematoma. } \\
\text { Intraparenchymal Haematoma }>5 \mathrm{~cm}\end{array}$ \\
\hline & Laceration & $\begin{array}{l}>3 \mathrm{~cm} \text { Parenchymal Depth or } \\
\text { Involving Trabecular Vessels }\end{array}$ \\
\hline IV & Laceration & $\begin{array}{l}\text { Laceration of Segmental or } \\
\text { Hilar Vessels Producing Major } \\
\text { Devascularization ( }>25 \% \text { Of Spleen) }\end{array}$ \\
\hline \multirow[t]{2}{*}{ V } & Laceration & Completely Shattered Spleen \\
\hline & Vascular & $\begin{array}{l}\text { Hilar Vascular Injury with } \\
\text { Devascularised Spleen }\end{array}$ \\
\hline
\end{tabular}

The 19 Splenic Injuries were Graded Accordingly

\begin{tabular}{|c|c|}
\hline Grade & No. of Cases \\
\hline I & 5 \\
\hline II & 7 \\
\hline III & 1 \\
\hline IV & 3 \\
\hline V & 2 \\
\hline
\end{tabular}

In one case Grade-II splenic injury was missed on CECT and was reported as Haemoperitoneum with no obvious solid organ injury which was later detected on surgery.

\section{Liver Injury}

Liver injuries were the next most common form of abdominal trauma cases after the spleen. Liver injuries were graded according to the table given below-

\begin{tabular}{|c|c|c|}
\hline Grade* & $\begin{array}{l}\text { Type of } \\
\text { Injury }\end{array}$ & Description of Injury \\
\hline \multirow{3}{*}{ I } & Hematoma & Subcapsular, $<10 \%$ Surface Area \\
\hline & Laceration & Capsular Tear, $<1 \mathrm{~cm}$ \\
\hline & & Parenchymal Depth \\
\hline \multirow[t]{3}{*}{ II } & Hematoma & $\begin{array}{l}\text { Subcapsular, } \\
10 \% \text { To } 50 \% \text { Surface Area }\end{array}$ \\
\hline & & Intraparenchymal $<10 \mathrm{~cm}$ in Diameter \\
\hline & Laceration & $\begin{array}{l}\text { Capsular Tear 1-3 Parenchymal Depth, } \\
<10 \mathrm{Cm} \text { in Length }\end{array}$ \\
\hline \multirow[t]{2}{*}{ III } & Hematoma & $\begin{array}{l}\text { Subcapsular, }>50 \% \text { Surface Area of } \\
\text { Ruptured Subcapsular or } \\
\text { Parenchymal Hematoma; } \\
\text { Intraparenchymal Hematoma }>10 \mathrm{Cm} \\
\text { or Expanding }\end{array}$ \\
\hline & Laceration & $>3 \mathrm{~cm}$ Parenchymal Depth \\
\hline \multirow[t]{2}{*}{ IV } & Laceration & $\begin{array}{l}\text { Parenchymal Disruption Involving } \\
25 \% \text { To } 75 \% \text { Hepatic Lobe or }\end{array}$ \\
\hline & & 1-3 Couinaud's Segments \\
\hline \multirow[t]{4}{*}{ V } & Laceration & $\begin{array}{l}\text { Parenchymal Disruption Involving } \\
>75 \% \text { of Hepatic Lobe or }>3\end{array}$ \\
\hline & & $\begin{array}{l}\text { Couinaud's Segments Within a } \\
\text { Single Lobe }\end{array}$ \\
\hline & Vascular & $\begin{array}{l}\text { Juxta Hepatic Venous Injuries; } \\
\text { i.e. Retro Hepatic Vena }\end{array}$ \\
\hline & & Cava/Central Major Hepatic Veins \\
\hline VI & Vascular & Hepatic Avulsion \\
\hline
\end{tabular}

The 11 Liver Injuries were Graded Accordingly

\begin{tabular}{|c|c|}
\hline Grade & No. of Cases \\
\hline I & 5 \\
\hline II & 3 \\
\hline III & 0 \\
\hline IV & 2 \\
\hline V & 1 \\
\hline
\end{tabular}

Out of 11 liver injuries 8 cases i.e. 72\% (GR-I, 5 cases; GRII, 3 cases) were managed conservatively, and 3 cases i.e. 28\% (GR-IV, 2 cases; GR-V, 1 case) treated operatively. GR-V injury case also showed active extravasation of contrast. In 3 
cases which were operated MDCT identified all the injuries correctly.

\section{Renal Injuries}

Out of 46 injured organs 6 cases were identified to be of renal injury. Renal injuries were graded according to the table given below:

\begin{tabular}{|c|c|l|}
\hline Grade & $\begin{array}{c}\text { Type of } \\
\text { Injury }\end{array}$ & \multicolumn{1}{|c|}{ Description of Injury } \\
\hline \multirow{2}{*}{ I } & Contusion & $\begin{array}{l}\text { Microscopic or Gross Hematuria, } \\
\text { Urologic Studies Normal }\end{array}$ \\
\cline { 2 - 3 } & Hematoma & $\begin{array}{l}\text { Subcapsular, Nonexpanding without } \\
\text { Parenchymal Laceration }\end{array}$ \\
\hline \multirow{2}{*}{ II } & Hematoma & $\begin{array}{l}\text { Nonexpanding Perirenal Hematoma } \\
\text { Confirmed to Renal }\end{array}$ \\
\cline { 2 - 3 } & & Retroperitoneum \\
\cline { 2 - 3 } & Laceration & $\begin{array}{l}<1.0 \text { cm Parenchymal Depth of Renal } \\
\text { Cortex Without Urinary Extravagation }\end{array}$ \\
\hline \multirow{2}{*}{ III } & Laceration & $\begin{array}{l}<1.0 \text { cm Parenchymal Depth of Renal } \\
\text { Cortex without Collecting System } \\
\text { Rupture or Urinary Extravagation }\end{array}$ \\
\cline { 2 - 3 } & Laceration & $\begin{array}{l}\text { Parenchymal Laceration Extending } \\
\text { Through Renal Cortex }\end{array}$ \\
\hline \multirow{2}{*}{ IV } & & Medulla and Collecting System \\
\cline { 2 - 3 } & Vascular & $\begin{array}{l}\text { Main Renal Artery or Vein Injury with } \\
\text { Contained Haemorrhage }\end{array}$ \\
\hline \multirow{2}{*}{ V } & Laceration & Completely Shattered Kidney \\
\cline { 2 - 3 } & Vascular & $\begin{array}{l}\text { Avulsion of Renal Hilum Which } \\
\text { Devascularises Kidney }\end{array}$ \\
\hline
\end{tabular}

The 6 Renal Injuries were Graded Accordingly

\begin{tabular}{|c|c|}
\hline Grade & No. of Cases \\
\hline I & 3 \\
\hline II & 1 \\
\hline III & 0 \\
\hline IV & 1 \\
\hline V & 1 \\
\hline
\end{tabular}

Of the 6 patients, one patient had shattered kidney (GR-V) and one had GR-IV injury and were associated with other organ injuries. Nephrectomy was done in both cases. There were 3 cases of GR-I and 1 case of GR-II injury and these cases were managed conservatively. One case of extra peritoneal bladder injury was seen and was operated.

\section{Bowel Injury}

Out of 46 injured organs, 4 cases were identified to be of bowel injury. All four had pneumoperitoneum on MDCT. Three cases had moderate haemoperitoneum. In one case, focal wall thickening of jejunum with small rent in the wall was noted which, was confirmed on surgery as jejuna perforation. In one case there was focal wall thickening of ileum seen which was confirmed on surgery as ileal perforation. In two other cases, no evidence of localising signs were observed but on surgery they were detected as ileal perforation.

\section{Mesenteric Injury}

Out of 46 organ injuries, 3 cases were mesenteric injuries. Two cases had moderated haemoperitoneum and one had large haemoperitoneum. In one case mesenteric tear with injury to SMA and extravasation of contrast was seen. In two other cases haemoperitoneum with no obvious solid organ injury reported. On surgery, mesenteric tear was detected in two cases.

\section{Pancreatic Injury}

Out of the 46 injured organs, only 1 case was attributed to the pancreas. Pancreatic injuries were graded according to the table given below-

\begin{tabular}{|c|c|l|}
\hline Grade & Type of Injury & \multicolumn{1}{|c|}{ Description of Injury } \\
\hline \multirow{2}{*}{ I } & Hematoma & $\begin{array}{l}\text { Minor Contusion without Duct } \\
\text { Injury }\end{array}$ \\
\cline { 2 - 3 } & Laceration & $\begin{array}{l}\text { Superficial Laceration without } \\
\text { Duct Injury }\end{array}$ \\
\hline \multirow{2}{*}{ II } & Hematoma & $\begin{array}{l}\text { Major Contusion without Duct } \\
\text { Injury or Tissue Loss }\end{array}$ \\
\cline { 2 - 3 } & Laceration & $\begin{array}{l}\text { Major Laceration without Duct } \\
\text { Injury or Tissue Loss }\end{array}$ \\
\hline \multirow{2}{*}{ III } & Laceration & $\begin{array}{l}\text { Distal Transection or } \\
\text { Parenchymal Injury with Duct } \\
\text { Injury }\end{array}$ \\
\hline \multirow{2}{*}{ IV } & Laceration & $\begin{array}{l}\text { Proximal? Transection or } \\
\text { Parenchymal Injury Involving } \\
\text { Ampulla }\end{array}$ \\
\hline V & Laceration & $\begin{array}{l}\text { Massive Disruption of Pancreatic } \\
\text { Head }\end{array}$ \\
\hline
\end{tabular}

This case was classified as GR-III splenic injury and the patient was operated for splenic injury but the pancreas injury, was graded as GR-II and was managed conservatively.

\section{CONCLUSION}

The present study concluded that Intravenous Contrast Enhanced MDCT is the imaging modality of choice in effectively evaluating blunt trauma abdomen in haemodynamically stable patients. As there is a considerable decrease in the usage of diagnostic peritoneal lavage and also the preference for non-surgical therapy, the use of MDCT appears to be the most specific and sensitive in diagnosing and grading solid organ injury. Solid organ injury grading system is very useful in deciding treatment options along with clinical evaluation by the surgeon. Exact localization of bowel injury is not possible but presence of pneumoperitoneum and associated focal bowel wall thickening indicate bowel injury. Direct visualization of mesenteric injury is also not possible with CECT, presence of Haemoperitoneum with no detectable solid organ injury is highly suggestive of mesenteric tear. With increased nonoperative management of blunt abdominal trauma, accurate diagnosis and grading of injuries with CECT mandatory. MDCT abdomen not only detects intra-abdominal injury, but also detects other associated important injuries such as haemothorax, lung injuries, fractures of lower ribs, fractures of spine and pelvis.

\section{REFERENCES}

[1] Stone CK, Humphries RL. Current diagnosis \& treatment: emergency medicine. $6^{\text {th }}$ edn. McGrawHill Medical Publishing 2007.

[2] Colucciello SA. Blunt abdominal trauma. Emerg Med Clin North Am 1993;11(1):107-23.

[3] Root HD, Hauser CW, Mckinley CR, et al. Diagnostic peritoneal lavage. Surgery 1965;57:633-7. 
[4] Gonzalez M, Bucher P, Ris F, et al. Splenic trauma: predictive factors for failure of non-operative management. J Chir (Paris) 2008;145(6):561-7.

[5] Bode PJ, Edwards MJ, Kruit MC, et al. Sonography in clinical algorithm for early evaluation of 1671 patients with blunt abdominal trauma. AJR Am J Roentgenol 1999;172(4):905-11.

[6] Stengel D, Bauwens K, Sehouli J, et al. Systematic review and meta-analysis of emergency ultrasonography for blunt abdominal trauma. Br J Surg 2001;88(7):901-12.

[7] Federle MP, Goldberg HI, Kaiser JA, et al. Evaluation of abdominal trauma by computed tomography. Radiology 1981;138(3):637-44.

[8] Catre MG. Diagnostic peritoneal lavage versus abdominal computed tomography in blunt abdominal trauma: a review of prospective studies. Can J Surg 1995;38(2):117-22.

[9] Gonzalez RP, Ickler J, Gachassin P. Complementary roles of diagnostic peritoneal lavage and computed tomography in the evaluation of blunt abdominal trauma. J Trauma 2001;51(6):1128-34.
[10] Rhea JT, Novelline RA, Lawrason J, et al. The frequency and significance of thoracic injuries detected on abdominal CT scans of multiple trauma patients. J Trauma 1989;29(4):502-5.

[11] Miller LA, Shanmuganathan K. Multidetector CT evaluation of abdominal trauma. Radiol Clin North Am 2005;43(6):1079-95.

[12] Cox EF. Blunt abdominal trauma. A 5-year analysis of 870 patients requiring celiotomy. Ann Surg 1984;199(4):467-74.

[13] Boscak A, Shanmuganathan K. Splenic trauma: what is new? Radiol Clin North Am 2012;50(1):105-22.

[14] Sclafani SJ, Weisberg A, Scalea TM, et al. Blunt splenic injuries: nonsurgical treatment with CT, arteriography, and transcatheter arterial embolization of the splenic artery. Radiology 1991;181(1):189-96.

[15] Shanmuganathan K, Mirvis SE. CT scan evaluation of blunt hepatic trauma. Radiol Clin North Am 1998;36(2):399-411.

[16] Velmahos GC, Toutouzas K, Radin R, et al. High success with non-operative management of blunt hepatic trauma: the liver is a sturdy organ. Arch Surg 2003;138(5):475-80. 